\title{
"Campesinos" and the crisis of modernization in Latin America
}

\author{
William M. Loker
}

\begin{abstract}
We want democracy to be a reality in all the spaces of our respective national societies: in the economic, political, social and cultural. To achieve this we must act. It is necessary to criticize, to show errors, deficiencies, faults, and injustices, but at the same time we must propose solutions to the problems we confront. These solutions should emerge from a broad, frank, and fraternal exploration that leads to consensus. It should result from the conscious participation of distinct social sectors at the local, regional, continental, and global levels. Nobel Laureate, Rigoberta Menchú Tum, April 10, 1996 (Translated by author.)
\end{abstract}

\section{Introduction}

Latin America ${ }^{1}$ has experienced a number of significant changes in recent years that force us to rethink our approaches to understanding people and their livelihoods in the region. These forces include urbanization, liberalization, and democratization. These three terms capture a complex series of events, policy measures, and social forces that are transforming the Latin American social, political and economic landscape. Despite these sweeping changes, the problem of mass poverty persists and is once again rising to the forefront of the political agenda. The number of poor has increased both in percentage terms and in absolute numbers compared to 25 years ago. Poverty remains concentrated in rural areas; a higher percentage of rural dwellers live in poverty compared to urban dwellers. But as Table 1 indicates, in terms of absolute numbers, for the first time in history, there are now more poor people living in urban than in rural areas of Latin America.

The changes mentioned come in the aftermath of the "lost decade" of the 1980s (the height of the debt crisis era) with its frustrated economic expectations. One pervasive lesson of the debt crisis was the vulnerability of Latin American economies to external economic events and their subordination in the global political economic context to the demands of international institutions and creditors. The example of Peru's economic disaster, when populist president Alan Garcia pursued a "heterodox" economic strategy including unilateral limits set on debt repayments (in defiance of international creditors),

1. Latin America is a heterogeneous region. This paper focuses primarily on Mexico, Central America, and tropical South America. Even within this group of countries there is obviously significant variation in terms of the structure of agriculture, the number of campesinos, the role of agriculture in the economy, and other relevant variables. The paper attempts to discuss general trends, using a number of country-specific examples. 
has not been lost on other Latin leaders (see Pastor and Wise 1992 for a review of the

TABLE 1. Changes in the magnitude of poverty in Latin America, 1970-1990a

\begin{tabular}{|c|c|c|c|c|c|c|}
\hline \multicolumn{4}{|c|}{ Poor $\underline{\mathbf{b}}$} & \multicolumn{3}{|c|}{$\underline{\text { Absolute poor }}{ }^{\mathrm{c}}$} \\
\hline \multicolumn{7}{|c|}{ (percentage of total population) } \\
\hline 1970 & 45 & 29 & 67 & 24 & 13 & 40 \\
\hline 1980 & 41 & 30 & 60 & 19 & 11 & 33 \\
\hline 1990 & 46 & 39 & 61 & 22 & 15 & 37 \\
\hline \multicolumn{7}{|c|}{ (millions of people) } \\
\hline 1970 & 119.8 & 44.2 & 75.6 & 63.7 & 19.9 & 43.8 \\
\hline 1980 & 135.9 & 62.9 & 73.0 & 62.4 & 22.5 & 39.9 \\
\hline 1990 & 195.9 & 115.5 & 80.4 & 93.5 & 44.9 & 48.6 \\
\hline \multicolumn{7}{|c|}{ (absolute poor as percentage of poor) } \\
\hline & & $\underline{\text { Total }}$ & $\underline{\text { Urban }}$ & $\underline{\text { Rural }}$ & & \\
\hline 1970 & & 53 & 45 & 58 & & \\
\hline 1980 & & 46 & 36 & 55 & & \\
\hline 1990 & & 48 & 39 & 60 & & \\
\hline
\end{tabular}

a. Source IFPRI, 1995

b. "Poor" Individuals have incomes inadequate to meet minimum daily nutritional requirements, as well as other needs such as hygiene, clothing, education, and transportation.

c. "Absolute poor" have incomes inadequate to supply minimum daily nutritional needs even if other basic needs are foregone.

Peruvian "heterodox" experience). If poor countries require access to foreign capital as a prerequisite for the economic growth that is the necessary, but not sufficient, condition for reducing poverty, then Latin American governments realized as never before that they had to play the economic development game by rules set in Washington, Paris, Bonn and Tokyo or risk dramatic economic declines.

These rules include the "downsizing" of government via a dramatic wave of privatizations, a reduction in the state's role in economic planning and policymaking, and often dramatic cuts in government-supplied social services in accordance with the dictates of structural adjustment packages. These measures have been adopted with varying degrees of enthusiasm in countries from Chile to Mexico, sometimes externally imposed, sometimes eagerly generated by national governments. That these events were played out against the backdrop of the collapse of communism and the break-up of the Soviet Union only served to drive home the dictates of capitalist development with greater force. The result is that Latin America countries are now inserted in the world economy in new ways that directly affect the livelihoods and survival strategies of the rural poor.

This paper examines the implications of recent macro changes for Latin American campesino communities. It discusses the widely perceived social, economic, and 
ecological crises in these communities as well as responses of members of these communities to these changes. Some of the processes described are linked to the effects of "structural adjustment programs." Others are more closely linked to what has been termed "globalization." In reality, it is difficult to analytically separate the two phenomena. In all cases, the effects of these changes are viewed against the historic pattern of the neglect of the rural poor in Latin America.

\section{What are "campesinos" and is the term peasant useful?}

In this paper I consciously use the term "campesino" and conspicuously avoid the term "peasant." There is a long debate in the study of Latin American agrarian systems regarding the appropriateness of the term "peasant" or "farmer" for rural dwellers (see M.Kearney 1996 for a recent review of these debates). Kearney's review draws our attention to the proliferation of livelihood strategies and self-identities experienced by (post-) modern campesinos. Kearney who emphasizes the disjunctions between contemporary campesinos and those labeled "peasants" in the past, rejects the analytical utility of the term "peasant" and probably "campesino" as well. This reflects his work with the increasingly trans-national campesinos of Oaxaca and California (creatively termed "Oaxacalifornians.") My own experience with less transnationalized rural dwellers in Honduras and Peru leads me to retain the concept of "campesino" to identify relatively poor, predominantly rural dwellers with strong ties to agriculture either as producers, laborers, or more frequently, both. There is some precedent for rejecting the term peasant while retaining the "maddeningly vague" term campesino (W. Roseberry 1993:362n). "Campesino" translates literally as "person of the country" and is often glossed as "peasant" in English. I prefer the term campesino because it applies to many rural dwellers who are increasingly involved in a variety of economic activities, including, but not limited to, farming. ${ }^{2}$ Those that are engaged in agriculture fall predominantly into the group termed "resource poor farmers" (R. Chambers \& J. Jiggins 1987a,b). Resource poverty applies to diverse situations such as: lack of cash income, lack of land, poor quality land, lack of capital, lack of access to institutional resources (credit, technical assistance), lack of access to education, health care, and other resources. Latin American campesinos suffer some or all of these characteristics.

Other characteristics of campesinos can ultimately be traced to their poverty: they often engage in diversified agriculture on relatively small farms, frequently in areas of dense population. ${ }^{3}$ Because they are poor in assets and income, there follows a series of social characteristics of campesinos, including: (1) a heavy dependence on household labor (self-exploitation), as hiring wage labor cuts into valuable cash reserves; (2) diverse

2. Rural communities include a variety of people including school teachers, government officials and others with few long-term ties to the land or community. This paper focuses more on those rural dwellers who share both poverty and some ties to the land and agriculture within the context of diverse livelihood strategies.

3. The terms "dense population" and "small farm" are relative to the social and ecological context. A small farm may be half a hectare or less in the Guatemalan Highlands, or 5 hectares in the Peruvian Upper Amazon. 
production strategies in terms of producing food crops for cash sale and home

TABLE 2. Sources of income of the campesino sector in various Latin American countries $^{\mathrm{a}}$

\begin{tabular}{|c|c|c|c|c|c|}
\hline Region & Year & $\begin{array}{l}\text { Farm Size } \\
\text { (hectares) }\end{array}$ & $\begin{array}{l}\text { Percent } \\
\text { Farm }\end{array}$ & $\begin{array}{l}\text { of income } \\
\text { Wages }\end{array}$ & $\begin{array}{l}\text { from: } \\
\text { Other }\end{array}$ \\
\hline Cajamarca, Peru & 1973 & $0-3.5$ & 23 & 50 & 27 \\
\hline Puebla, Mexio & 1970 & $0-4$ & 32 & 58 & 11 \\
\hline $\begin{array}{l}\text { Garcia Rovia, } \\
\text { Columbia }\end{array}$ & 1972 & $0-4$ & 79 & 16 & 5 \\
\hline South Bolivia & 1977 & $0-5$ & 38 & $62^{\mathrm{b}}$ & \\
\hline Region IV, Chile & 1976 & $0-5$ & 47 & 40 & 13 \\
\hline Vertentes,Brazil & 1979 & $0-10$ & n.d. & $56^{\mathrm{c}}$ & n.d. \\
\hline $\begin{array}{l}\text { NW Highlands, } \\
\text { Guatemala }\end{array}$ & 1978 & $0-3.5$ & 29 & 59 & 12 \\
\hline El Salvador & 1975 & $0-2$ & 64 & 27 & 9 \\
\hline Sierra, Ecuador & 1974 & $0-5$ & 37 & 44 & 19 \\
\hline Coast, Ecuador & 1974 & $0-5$ & 48 & 41 & 11 \\
\hline Chamula, Mexico & 1973 & n.d. & 11 & $89^{b}$ & \\
\hline
\end{tabular}

consumption, as well as market-oriented cash crops; (3) diverse income generating strategies on- and off-farm: as land becomes more scarce, there is an increased dependence on off-farm labor (See Table 2). For example, in Guatemala one study of the small farm sector found that 44 percent of farms earned more than 60 percent of income from off-farm labor, 17 percent earned 10-60 percent from off-farm sources and 38 percent earned less than 10 percent from off-farm labor (J. von Braun and D. Hotchkiss 1991:71). And of course, increasing numbers of campesinos are landless altogether. More than 60 percent of the rural population in El Salvador is landless, and there are more than 400,000 rural landless households in Guatemala (G. Elbow 1989:413, 401). Therefore, campesinos are increasingly dependent on various forms of tenancy and wage labor for survival. The resource poverty of campesinos leads also to a subordinate social status locally and nationally. The vulnerable position of "resource poor farmers" and landless campesinos leads to vertical relationships of dependency (peón-patrón) used as a social resource in a diversified survival strategy, including personalismo, compadrazgo other social mechanisms that deal with chronic poverty. Many of these mechanisms are on the wane as the "moral economy" is increasingly "rationalized" to gain efficiencies of production. Campesino communities are also characterized by the importance of horizontal social relationships to help ensure survival: kin-based labor sharing, fiestas, and 
shared poverty. When these characteristics are combined in a historically enduring pattern, people become characterized as "peasants." But because of the increasingly diverse livelihood strategies pursued in the countryside, and the growing importance of off-farm labor, it becomes more useful semantically and conceptually to see this diverse group of rural dwellers as simply, campesinos: people of the country.

\section{Campesinos in crisis}

Campesino communities are in crisis. The nature of this crisis varies by country, by region within countries, and even from community to community. But there are common elements to this crisis associated with the structural position of campesinos within national economies. This crisis is linked to the changing overall economic context of Latin American countries briefly described above, throughout the national economies of these countries. Campesino communities are directly affected by, and respond to, these changes. The basic outlines of these forces have been outlined by A. de Janvry, et al.

The Latin American peasantry has been the victim of a "double (under-) development squeeze.".... On the one side, the peasantry has been unable to protect access to land and average farm size has been declining, forcing peasant households to seek sources of income outside the farm.... At the same time, employment opportunities... have grown slowly, permanent workers have been increasingly replaced by seasonal workers.... scholars of peasantry have heatedly debated whether peasants would increase in numbers by successfully competing with family farms (Warman 1972; Servolin 1972) or would decrease in numbers [and]... be transformed into landless proletarian workers.... Neither position is correct. Peasants do increase in numbers-but as a sign of systemic failure in providing them with sufficient employment.... Peasants become increasingly dependent on wage earnings as a component of household income--but without becoming landless as they maintain continued access to a plot of land, however small. With peasants thus existing as a residual category, with insufficient access to either land or employment... they account for the bulk of poverty in Latin America (1989: 396-397).

This "double underdevelopment squeeze" has had a number of consequences for individuals, households and communities trying to survive this crisis. These consequences have been documented by a number of researchers in the region (see for example $\mathrm{M}$. Painter and W. Durham 1995; S. Stonich 1993; D. Murray 1994) and modelled by J. Vandermeer and I. Perfecto (1995) and W. Durham (1995) (See Figures 1 and 2.)

The authors cited above agree substantially in their views of the causes of this crisis. The main areas of agreement include:

(1) a dualistic pattern of agricultural production into commercial/export sectors and subsistence/basic grain sectors, linked by the wage labor of subsistence/grain farmers in the export sector;

(2) resources are highly inequitably distributed in the two sectors, with the export sector expanding its land base at the expense of smaller producers and the natural environment;

(3) preferential treatment by the government of both urban sectors (M. Lipton's urban bias 1977) and the export-agriculture sector;

(4) growing population and a stagnant or declining resource base (land), and;

(5) campesino efforts to intensify (adoption of chemical inputs) or extensify (expand into previously uncultivated areas) often lead to environmental degradation. 
The end result is that campesinos resort to increasingly disparate and desperate livelihood strategies. These include local agricultural labor within the community or region, migrant agricultural labor in the export agriculture sector, and cyclical urban and international migration, all of which divert productive labor from agriculture, making efforts at sustainable intensification of agricultural production more problematic. Campesino households seeking to diversify income sources are often fragmented; members of the household live in various places at different times and come together on rare occasions. The traditional view of campesino households as coresident, cooperative groups sharing a common labor pool oriented largely to agricultural production is increasingly a myth. For example, the growing maquiladora sector in Central America draws heavily on young women from the countryside as a source of cheap labor. Despite difficult working conditions and low wages, women and girls eagerly seek these employment opportunities, to escape the economic and social constraints of the countryside. They often work for extended periods in factories, sending a portion of wages home to subsidize the (rural) household. Periodically they leave the wage-labor sector and return to the countryside for extended periods of time, re-incorporating themselves in the household labor pool (based on personal observations in the El Cajún region of Honduras, see also S. Stonich 1993). Central America is thus following the Mexican pattern of increased importance of remittance income for the survival of rural households and communities (see Durand and Massey 1992:25ff for a review of the importance of remittances in rural Mexico).

The double squeeze on the rural poor also leads a significant portion of households to colonize "frontier" zones of agricultural expansion, inducing deforestation and often ephemeral productivity gains in these fragile ecosystems, and causing social conflict between colonists and indigenous inhabitants. This process may be combined with retaining residence in the home community, as documented by Collins (1988) in Southern Peru, or it may be permanent as observed in numerous colonization efforts in Amazonia. Aramburœ (1984:163) estimates that of every five migrants that leave the Peruvian Sierra, four go to the coast (mostly to urban areas), and one goes to the tropical forest region. Jones (1990) and Stonich (1993) discuss links between highland poverty and lowland colonization in Honduras. Vandermeer and Perfecto (1995) document a similar pattern in Costa Rica. Thus the crisis in long-, and relatively densely settled highland regions is indirectly responsible for environmental degradation in the lowland humid tropics. Increased population pressure, land shortage, and an acute shortage of capital, often induce unsustainable intensification of agricultural practices in campesino communities. The well-known process of shortening fallows in low-input agricultural systems leads to a downward cycle of lower yields, loss of agricultural fertility, soil erosion, and other negative consequences (Trenbath, Conway and Craig 1990). Small farmers may attempt to reverse this process by the adoption of chemical inputs, but these are often inappropriately used and unsafely used, causing further environmental deterioration and creating health problems among those handling these products. Marketing channels and dispersed, unorganized buying patterns often lead to high costs of inputs to campesinos and high middleman profits.

The increased "rationalization" of production among larger farmers, including mechanization (often subsidized by government policies such as fuel subsidies, input subsidies, imports of agricultural machinery) leads to a decline in wage-labor opportunities in agriculture, as well as a decline in the personalistic bonds that formed an important social component of campesino survival strategies: patron-client relationships, 
compadrazgo, and other social mechanisms that blunted the severity of gross income inequality and assisted the survival of vulnerable groups in the countryside. The drive toward economic efficiency undermines long-standing cultural precedents of social solidarity, however hierarchical and paternalistic these may have been. The end result is increased vulnerability among marginal households, groups and individuals.

The "double squeeze" of declining land and declining employment opportunities is occurring in a context of shrinking government resources to cope with the social problems generated by these multiple, interlocking social, economic, and ecological crises. The responses of campesinos to this failure of the state to guarantee the basic conditions for earning a livelihood have been varied but they include migration, diversification, and the seeking of alliances with non-governmental organizations that have sprung up to fill the vacuum left by the withdrawal of the state.

\section{Why has the campesino sector been marginalized by government policy?}

The current crisis in campesino communities has its origins in the historical neglect of this sector by national governments. There are numerous reasons why campesinos have been neglected in Latin American development and why, despite their evident persistence, they are expected to (and in many cases it is hoped that they will) "disappear." Perhaps foremost among these reasons is the industrial bias in development: industrialization has been seen as the sine qua non of development. Rich countries are industrialized. Industrialization increases labor productivity. Industrialization has been seen by many as the escape from the trap of dependency on export of primary goods. In this view, agriculture's role in development is viewed solely as the sector that contributes to industrialization through transfer of resources (capital and labor) to industrialization (A. Lewis 1958; cf. B. Johnston and J. Mellor 1961). The industrial bias is reinforced by an urban bias in development (see M. Lipton 1977): political leaders are from cities, and urban life is more highly valued by most of those who hold positions of power and influence. Also, the concentration of population in cities has made it politically imperative and expedient to serve urban interests. This is compounded by the historically weak grassroots development of political parties due to urban origins and structural barriers to participation of rural people (dispersion, lack of skills and education, and other similar barriers). There is also an export/capital intensive bias in agricultural development: when attention has turned to the countryside, the focus has been on larger, more heavily capitalized production units because this approach fits with developed world model (export led, tractorism), and because it is easier to work with resource-rich farmers who are fewer in number, easier to reach, more educated, wealthy, and influential. Also, the export sector contributes foreign exchange for industrialization, and the payment of foreign debt obligations.

Many of these biases simply reflect prevailing class and power biases in development; in fact, some would see these as underlying the biases enumerated above. What is interesting is that so-called revolutionary governments have seldom favored campesinos or sought "campesino-led" development. In nonrevolutionary situations (by far the majority) class and power interests tend to channel development resources to ruling elites, such as urban industrialists and export agriculturalists (often the same individuals), not to campesinos. In revolutionary situations, campesinos are not understood or trusted, are 
seen as "lacking revolutionary potential," and generally as a "backward sector" that should ultimately "disappear." Netting, writing of "smallholders," comments that:

It is intriguing that for both the socialists.. of the left and the free-market capitalists of the right, the agreed-upon path to agricultural development has been the largescale, mechanized, energy-dependent, scientific, industrialized farm. Smallholders have been universally stigmatized as unproductive, regardless of their yields per unit of land, on the grounds that (1) they use too much labor; (2) they do not produce a large surplus for the market, and (3) they do not make rational economic, scientific decisions about production and innovation (R Netting 1993:21).

In summary, the prevailing development model sees campesinos as antimodern -- the antithesis of development--not as human beings whose needs require attention. If the rest of the modernization program is followed, their needs will somehow be taken care of, almost in passing, as a by-product of development of other sectors of the economy (industry, capital-intensive export agriculture). This seems true whether we are talking about the modernization paradigm of the 1950s or the neoliberal development paradigm of the 1990s (structural adjustment, export-led growth, comparative advantage). Campesinos are seen as having a comparative advantage of zero with no constructive role in the national economy or the global division of labor. Campesinos simply do not fit into the predominant development paradigm, yet: there they are!

With the recent "environmental turn" in development discourse, campesinos have been further demonized as the destroyers of the land, degraders, deforesters, short-sighted abusers of biological resources and otherwise enemies of sustainable development either out of ignorance, desperation or both. All these factors lead to a conceptualization of campesinos as a residual category, as 'surplus population,' and as 'obstacles to development.' As if development were something that can occur outside of efforts to realize the human potential of millions of people.

\section{What is development?}

It is impossible in 1997 to use the term "development" uncritically. Criticisms of the term have been deep, trenchant, unremitting and framed from a variety of perspectives: from left and right, green and red, socialist and capitalist, modern and postmodern. Given the current intellectual popularity of the postmodern perspective in the social sciences and humanities, I will focus on this perspective (drawn heavily from M. Hopenhayn 1993). I will also offer a modest definition of what I mean by the term development.

Postmodernists have critiqued development as totalizing, metanarrative reflecting a misplaced belief in progress, and one that promotes a vision of society that is imitative, culturally derivative and politically oppressive (W. Sachs 1992). Postmodernism tends towards a fascination with aesthetics and a rejection of historical determinism. This leads toward an ahistoric present orientation that rejects all conceptual models as totalizing and views plans for the future as coercive and utopic. The emphasis is on atomistic individualism, privileging agency to the neglect of structure. The rejection of metanarrative and "totalizing discourse" leads to an extreme relativism that trivializes conventional indicators of development such as access to health care and education.

As Hopenhayn (1993) points out, the postmodern critique can intentionally or unintentionally serve the interests of those who deny the responsibility of the rich countries for some measure of the underdevelopment of the less developed countries, and 
who argue for the elimination or reduction of assistance to the poor in developing countries. The exaltation of diversity leads to the exaltation of the market as the only social institution capable of bringing order without coercion, whereas the critique of intellectual and political vanguards and metanarratives leads to a critique of the transformational function of politics and of social planning. Postmodernism denies the existence of a value frame that stands apart from culturally situated discourse (such as some notion of "progress" or "emancipatory" activity), hence it is impossible to question the waste, alienation and growing inequality of modern industrial society. The postmodernist critique of ideologies includes a critique of Marxism and more humanistic socialist variants which are considered examples of "utopic" thought (and therefore, not to be trusted), as are their agendas of redistributing wealth or reducing inequality. In short, to the extent that postmodernism claims that there is no enduring value frame from which we can base our criticism of the status quo, it represents a dangerous path of intellectual disengagement from the pressing problems of mass poverty and exploitation. The postmodern critique should not blind us to the fact that people do have demonstrable needs and rights-- needs that are not being filled, and rights that are being violated in the current global system.

Development may simply mean increasing peoples' access to basic goods and services by increasing incomes (or entitlements) and facilitating wider, more equitable social participation by vulnerable, marginal groups. Guarantees of equitable social participation may be a necessary condition for development as it ensures the means necessary for the poor to articulate their rights and needs and mobilize to obtain the goods and services they need and deserve (H. Shue 1980). Notions of basic goods and services may vary somewhat from group to group but will almost invariably include aspects defined as "basic rights" by Shue (1980): access to an adequate, secure diet, access to medical care to avoid and cure disease, access to education, especially basic literacy and numeracy, to assist in meaningful participation in society, and security of person necessary for open participation in society in pursuit of self-determined goals, wants and needs.

\section{Globalization/Globaloney ${ }^{4}$ : campesinos aren't going away and why development needs to pay attention to them}

The main reason to pay attention to campesinos is their numbers and their poverty. Sources vary in their estimates of poverty in Latin America, but most agree that the number of poor is growing in absolute terms. The IFPRI source cited above (IFPRI 1995:1) estimates that 45 percent of the Latin American population is poor, and that the number of poor has increased from 120 million in 1970 to 200 million today. A 1995 World Bank conference estimated that one-third of Latin America's population (156 million) earns less than $\$ 3.00$ per day and 18 percent earn less than $\$ 1.00$ per day (Anonymous, 6/14/95). According to the Latin American and Caribbean Commission on Development and the Environment, in 1960, an estimated 110 million persons, representing 51 percent of the population, lived below the poverty line in Latin America

4. This term is adopted from Mac Chapin (1996). 
and the Caribbean. This percentage declined to 40 percent in 1970 and 35 percent in 1980. The situation was reversed in the 1980s -- Latin America's "Lost Decade" -- and now about 40percent of the population (about 148 million people) is estimated to live in poverty, of which 61 million live in extreme poverty. The absolute number of poor in 1985 was almost 50 percent greater than in 1960 and some 25 percent greater than in 1980 (Latin American and Caribbean Commission on Development and the Environment 1990:11 as quoted in E. Carrasco 1994:258).

Rates of rural poverty are extremely high in most Latin American countries (Table 3) ranging from an astonishing 95 percent of the rural population classified as poor in Haiti to over 75 percent of the rural population in Central America and Bolivia and over half of the rural population in all but 5 countries. For example, Harrell, Parillon and Franklin (1989) document the extent of malnutrition in Peru and conclude that about 38 percent of children in Peru suffered from some degree of malnutrition and that 70 percent of the most serious cases were found in children residing in households dependent on agriculture for production or wage work (1989:326). A recent report on rural poverty projects that, if current trends continue, the numbers of rural poor will increase from an estimated 126 million in 1988 to 153 million by the end of the century (FAO 1988:2).

While the number of rural poor is increasing, so is the number of urban poor and the incidence of urban malnutrition (N. Solomons and R. Gross 1987). "Between 1950 and 1980, there was a marked displacement in marginality away from the agricultural sector toward the urban economy... in all 17 countries where data area available, except Uruguay" (A. de Janvry, et al. 1989:402). Campesinos are drawn to the city by the expectation of higher wages and improved access to services. One trend of the past 35 years is a growing gap in rural versus urban wages, with the rural sector losing ground (FAO 1988). Yet economic growth and industrialization is not going to absorb campesinos. According to de Janvry, et al. (1989:400-404) economic growth appears to be increasingly less labor absorbing over time, presaging the continued existence of large marginal sectors in the countryside and the city over time, unless steps are taken to directly address this issue. The notion that agriculture should shed labor to supply workers for industry is obsolete. Johnston and Mellor's (1961) conceptual framework of an active role for agriculture in development saw a more expanded role for agriculture, including: (a) meeting a rapidly growing demand for agricultural products stemming from overall development, (b) foreign exchange earnings from agricultural exports, (c) a market of industrial output, and (d) supply capital for further agricultural, as well as industrial growth. The conceptual framework, however, still views agriculture as a source of labor for the nonagricultural sectors.

Instead of shedding labor for the nonagricultural economy, agriculture should be viewed as a sector to absorb labor, either directly in productive activities or through linkages to agriculturally-related activities like processing, marketing, and other services. Agriculture must provide sustainable, satisfying livelihoods for more, not less people. There are already too many people in the city and not enough jobs, as illustrated by the explosive growth of the informal sector, squatter settlements, and other indicators of urban economic marginality. Where is it easier to deal with poverty: in the city or in the countryside? Until recently it was thought that addressing poverty was easier in the city. But now, cities are so swamped, this is questionable. Yet, to staunch the flow of rural to urban migration, the countryside must be something more than a place to "warehouse" the poor, or the natural and social environments in rural areas will also be overwhelmed. 
TABLE 3. Estimated Rural Poverty in Latin America, 1980ª

\begin{tabular}{|c|c|c|c|c|c|c|}
\hline & $\begin{array}{l}\text { Percent } \\
\text { Poor }\end{array}$ & $\begin{array}{l}\text { Percent } \\
\text { Absolute } \\
\text { Poor }\end{array}$ & $\begin{array}{l}\text { Total } \\
\text { Rural } \\
\text { Pop. } \\
\text { (000s) }\end{array}$ & $\begin{array}{l}\text { Total } \\
\text { Rural } \\
\text { Poor } \\
\text { (000s) }\end{array}$ & $\begin{array}{l}\text { Total } \\
\text { Absolute } \\
\text { Poor } \\
\text { (000s) }\end{array}$ & $\begin{array}{l}\text { Rural } \\
\text { Poor } \\
\text { as\% of } \\
\text { Total Pop. }\end{array}$ \\
\hline Mexico & 68 & 26 & 23,348 & 15,877 & 6070 & 21 \\
\hline $\begin{array}{l}\text { Central Amer- } \\
\text { ica }\end{array}$ & 75 & 52 & 13,014 & 9,773 & 6,712 & \\
\hline Guatemala & 84 & 52 & 4,253 & 3,573 & 2,212 & 46 \\
\hline Honduras & 80 & 70 & 2,359 & 1,887 & 1,651 & 47 \\
\hline El Salvador & 76 & 55 & 2,913 & 2,213 & 1,602 & 44 \\
\hline Nicaragua & 80 & 50 & 1,291 & 1,033 & 646 & 36 \\
\hline Panama & 67 & 38 & 967 & 648 & 367 & 32 \\
\hline Costa Rica & 34 & 19 & 1,231 & 419 & 234 & 19 \\
\hline Andean Region & 69 & 31 & 24,778 & 17,089 & 7,725 & \\
\hline Columbia & 67 & 23 & 9,226 & 6,181 & 2,112 & 23 \\
\hline Ecuador & 65 & 20 & 4,279 & 2,781 & 856 & 31 \\
\hline Peru & 68 & 39 & 5,720 & 3,890 & 2,231 & 21 \\
\hline Bolivia & 86 & 74 & 3,102 & 2,668 & 2,295 & 48 \\
\hline Venezuela & 64 & 9 & 2,451 & 1,569 & 221 & 11 \\
\hline Brazil & 73 & 43 & 39,398 & 28,761 & 16,941 & 23 \\
\hline Southern Cone & 31 & 9 & 9,313 & 2,879 & 836 & \\
\hline Paraguay & 63 & 29 & 1,847 & 1,164 & 536 & 34 \\
\hline Chile & 56 & 11 & 2,106 & 1,179 & 232 & 10 \\
\hline Argentina & 10 & 1 & 4,890 & 489 & 49 & 2 \\
\hline Uruguay & 10 & 4 & 470 & 47 & 19 & 2 \\
\hline Caribbean & 78 & 41 & 9,266 & 7,217 & 3,777 & \\
\hline Haiti & 95 & 86 & 4,381 & 4,162 & 3,768 & 80 \\
\hline Jamaica & 51 & n.d. & 1,090 & 556 & n.d. & 25 \\
\hline $\begin{array}{l}\text { Dominican } \\
\text { Republic }\end{array}$ & 75 & n.d. & 2,751 & 2,063 & n.d. & 36 \\
\hline $\begin{array}{l}\text { Trinidad \& } \\
\text { Tobago }\end{array}$ & 40 & n.d. & 940 & 410 & n.d. & 34 \\
\hline Grenada & 25 & 9 & 140 & 26 & 9 & 24 \\
\hline
\end{tabular}

a. Source FAO, 1988.

Instead of shedding labor for the nonagricultural economy, agriculture should be viewed as a sector to absorb labor, either directly in productive activities or through 
linkages to agriculturally-related activities like processing, marketing, and other services. Agriculture must provide sustainable, satisfying livelihoods for more, not less people. There are already too many people in the city and not enough jobs, as illustrated by the explosive growth of the informal sector, squatter settlements, and other indicators of urban economic marginality. Where is it easier to deal with poverty: in the city or in the countryside? Until recently it was thought that addressing poverty was easier in the city. But now, cities are so swamped, this is questionable. Yet, to staunch the flow of rural to urban migration, the countryside must be something more than a place to "warehouse" the poor, or the natural and social environments in rural areas will also be overwhelmed.

Neglect of the campesino sector imperils other forms of development as well. It is well-known that campesinos are responsible for the production of major portions of basic grains in many Latin American countries. It is highly questionable whether Latin American countries should follow the logic of comparative advantage to its ultimate conclusion: the export of stimulants, fruits and sweets in exchange for grain grown in Iowa. In pursuing a comparative advantage strategy, food security issues loom large at every level: household, region, and nation. Although it is necessary to encourage agricultural exports, it is equally important to have a vibrant sector of farmers producing basic grains for domestic consumption. In many countries, campesinos can fill this niche. Campesinos are also guardians of genetic diversity maintaining land races of major crops, and diverse breeding stock of livestock. Neglect of the campesino sector can also imperil public health efforts to control epizootic and animal diseases such as swine fever and hoof-and-mouth disease. When campesino needs are neglected, their herds become reservoirs for continued outbreaks of such diseases.

The challenge is to take care of poverty in situ--in the countryside--rather than exporting it to cities or internationally. Transnational migration is real and growing, and will continue to grow. ${ }^{5}$ This is the ultimate logic of globalization. As other factors of production--financial capital and technology--have become internationally mobile, we can expect labor to become more internationalized, too. The flaw in this logic is, of course, that human beings are not simply "production factors" and their mobility can lead to serious social problems in terms of stress, alienation, and crime: the antithesis of development. To quote Polanyi, "To allow the market mechanism to be the sole director of the fate of human beings and their environment ...would result in the demolition of society. For the alleged commodity of 'labour power' can not be shoved about, used indiscriminately, or even left unused, without affecting also the human individual who happens to be the bearer of this peculiar commodity" (K.Polanyi 1994:73). It is not healthy for campesino families to be broken up by the cruel necessity of generating a livelihood from members spread out in a variety of occupations and locations. The stress

5. The criticisms of migration expressed here do not imply that all migration, whether rural to urban, national or international, is bad. Many individuals benefit from migration. But it is clearly the case that cities in developing countries are overwhelmed in terms of the provisioning of basic social services and suffer many human and environmental problems (see J. Hardoy, D. Mitlin and D. Satterwaite 1992 for a review of these problems). Also, it is unclear whether international migration is sustainable either in terms of solving local problems in rural communities or in terms of the growing political backlash in developed countries, e.g. Proposition 187 and similar initiatives in the U.S 
of desperately seeking centavos causes uncounted problems of mental and physical health in the countryside.

\section{Solutions}

The goal of development in many Latin American countries must be to create livable conditions for campesinos in the countryside. The means must be provided for people to produce, earn viable incomes, engage in environmentally sound production practices, and have access to the basics of development mentioned above: food, health, education, participation, security of person. Conditions in some rural areas are nightmarish. Stonich (1993) quotes one Honduran official as stating that "Going to the South (of Honduras) is good practice for going to Hell." Other areas are livable, but still need investment in infrastructure, targeted credit, technology, marketing infrastructure, and other basic services of a thriving rural economy. The precise mix of policies to make the countryside livable will vary, but in almost all areas providing health and education services is necessary in order to stop condemning campesinos who stay in rural areas to a life that is nasty, brutish, and short.

Netting (1993) has demonstrated that sustainable, productive smallholder agriculture is possible when these farmers are permitted access to the adequate resources. Land is but one--albeit a critically important one--of these resources. Land reform, despite its promise, is not being realistically considered in any Latin country. But Latin American states must be concerned with both distributive justice and economic productivity. The best way to guarantee both in the countryside is to provide a supportive political environment conducive to smallholders. There are a number of policy levers, short of confiscatory expropriation, that can serve to encourage smallholder success and welfare and discourage the speculative holding of large tracts of land. Not the least of these mechanisms is tax policy--a progressive tax on land holdings would most certainly encourage those holding large tracts of land in unintensive, highly uneconomic land uses, to divest, thereby making some of these lands available to smallholders. It is difficult to imagine, however, in general terms how those who lack them can acquire productive assets in an orderly manner, conducive to notions of fairness and the rule of law.

Other key elements to creating a liveable countryside are less mysterious. "(S)mallholders are relatively unanimous in their support for a good road network, big and honestly administered markets, and decent, accessible schools. As to what they cultivate and how they do it, when they sell their crops, and how they run their businesses, planners and bureaucrats should be cautioned against interference." (R. Netting 1993:325). Creating and facilitating a productive campesino sector in Latin America is not a simple matter of laissez faire capitalism. The market will not magically produce a vibrant rural economy and small farm sector. But, given a propitious policy environment, and access to land, a viable, productive, sustainable small farm sector is possible in the region, as is evident from the numerous examples reviewed in Wilken (1987). Revitalizing the countryside will require lots of money. The World Bank has estimated that an investment on the order of $\$ 600$ billion is necessary to bring infrastructure in Latin America up to speed after the neglect of the past ten years (Anonymous 1995). Although all of this investment is not targeted at rural infrastructure, a significant fraction of this must be spent in rural areas, if these are to become livable. If well targeted, such massive investment could repay substantial dividends in production and social harmony in the region. 
Is there any cause for optimism? Perhaps the most hopeful sign is the reduction in repression and the opening of political spaces for the articulation of people's social demands. Retrenchment of the state opens the possibility of a revitalization of civic society--institutional and organizational mechanisms for the articulation and fulfillment of people's wants and needs. Social and political participation is critical, but many campesinos remain unorganized and consequently unable to articulate their political demands. They display "All the organization of potatoes in a sack." (K. Marx 1971 (1852):230). And where organized, their demands often continue to be rebuffed, or repressed. But if people are permitted and encouraged to mobilize, as individuals, communities or in other collectivities, there is a chance that the state can become more responsive to the needs of the rural poor majority. But the window of opportunity of political participation will not remain open indefinitely. Continued frustration of the economic demands of marginal and vulnerable groups will lead to a loss of faith in the democratic process, despair, and the explosion of what Comaroff (1994:35) has termed the "anomic bomb:" the alienation, disempowerment and dispossession of vulnerable groups in countries around the globe.

General prescriptions for the campesino sector are difficult to generate, given the multiplicity of local situations in Latin America. In this sense, the postmodernists are probably right: metanarratives and grand prescriptions are of little use in tackling specific cases. Or as the famous postmodernist, Tip O'Neill put it, "All politics is local."

Yet if the conceptual models of Durham (1995) and Vandermeer and Perfecto (1995) are valid, they should serve as a point of departure for guiding prescriptive solutions in particular cases--that is, if applied researchers use theory generated by more basic research (c.f. M. Angorosino 1976). In both models the root causes of the crises affecting Latin American campesino communities are identified: skewed distribution of wealth, skewed development priorities and policies, and both of these exacerbated by rapid population growth. If these conceptual models are valid, what sorts of interventions are possible to accelerate positive social change? What are the roles of committed social scientists in accelerating positive social change? If local people know their situations best, what do social scientists bring to the table in terms of skills, services or "products" to facilitate change? Referring directly to the models posited by Durham (1995) and Vandermeer and Perfecto (1995), if the problems are deep-seated structural problems of inequality, what sorts of activities are possible? If revolutionary change is either not in the offing, or not the "product" social scientists have to offer, what alternatives remain? How can we work at the margins of a highly flawed system to help move social change in a more humane, equitable direction?

\section{Strategies of development}

There are at least two related, but conceptually distinct issues that need to be addressed. One is, How can marginalized campesinos be moved toward sustainable "smallholder" status, as outlined by Netting (1993)? This issue centers on improving agricultural production in terms of productivity, sustainability, and its ability to support a decent standard of living for those engaged in agriculture. Netting (1993:9) observes that: "Under certain circumstances of high population density and market economy, there is a viable smallholder alternative." What are these circumstances? What are the actions necessary, in terms of technology generation, policy reforms and institution building, 
necessary to create viable, sustainable smallholders? Again, the answers to these questions will be, to some extent, location specific. One of the most important contributions of social scientists, then, would be to provide the diagnostic skills to specify the circumstances under which smallholders can thrive, and the appropriate interventions in particular local situations to bring about these conditions.

It must be recognized, however, that not all of the rural population can or should be involved directly in agricultural production. The percentage that can be so oriented varies from region to region. This raises the second major issue: What becomes of the rest: those who lack access to land or other productive resources and probably always will? How can viable rural economies and societies be created? The key issue for this sector of campesino communities is employment generation (see J. von Braun 1995 for a recent review). Such employment will frequently involve activities linked to agriculture such as processing, marketing and other activities. Rural employment will also involve activities with few or no links to agriculture; however, the generation of local employment alternatives in construction, public works, or nonagricultural industries. In sum, the solutions to the campesino crisis increasingly lie outside production agriculture and are found in the broader rural economy. Dynamic agricultural production is necessary to generate surpluses, employment, and other economic linkages. But steps must be taken outside the agricultural sector as well to ensure increased well being.

The reminder that the development of viable rural communities involves much more than agricultural change may strike some as a throwback to the recommendations of an earlier development discourse: that of "integrated rural development" (IRD) and the "basic needs approach" prominent in the 1970s. IRD was criticized not so much for its goals, but because it was bureaucratic, cumbersome, expensive, and difficult (P. Streeten 1979). These are criticisms of the method of implementation, not of the goals of IRD. If the goals of IRD could be suffused with the current notion of participatory development, greater success is possible. The suggestion here is to reorient the implementation, while retaining the goals of IRD. The basic needs approach was criticized from both the right and the left. The right criticized this approach for attempting to promote social welfare without creating the material bases for economic growth. Neoliberalism is, to an extent, the ideological response to this criticism of the basic needs approach. But neoliberalism implemented with no social consciousness will only exacerbate inequality and undermine social stability. Basic needs was criticized form the left for selling the poor of developing countries short. Why basic needs? Why not aim for the same standards of consumption and well being enjoyed in the wealthy countries? If anything, the declining quality of life and worsening gap between rich and poor globally and regionally in Latin America make it more unfeasible than ever to propose a "great leap upward" in consumption levels for the poor majority. It also makes some form of development more imperative than ever.

I am not advocating a wholesale return to IRD efforts and the basic needs philosophy of 20 years ago. We have learned much in the intervening years. Among the most critical of these lessons is the importance of what local people themselves have to teach us (in terms of both indigenous technical and social knowledge), about the importance of participation, about the need to listen and respond to local concerns, rather than implement top-down approaches. There is a great need to identify successful instances of local response to the pervasive, multifaceted social and economic crises in campesino communities. Of particular importance is the emergence of new social movements in Latin America: NGOs and other self-help movements that are a potentially new paradigm for 
social participation in the emerging neoliberal context (A. Escobar and S.E. Alvarez 1992; R. Peet and M. Watts 1994).

Equally important is the realization that development occurs in a wider social, political and economic context. All politics may be local, but it is global as well. This is the central paradox of our age (B. Barber 1992). This implies recognizing the importance of the national and international contexts of development activities. Local knowledge is necessary, but not sufficient--if it were, there would be no problems to be remedied. Efforts may be focused on mobilizing the resources and energies of campesinos for "selfdevelopment" (autodesarrollo), but there must be a concerted effort to create the technical means, social institutions and political space to accomplish this. How can social scientists constructively engage in this process? Several suggestions have been proposed in the literature.

Cernea has suggested that the primary contribution of non-economic social scientists is to focus on patterns of social organization: revealing the models of social organization that underpin social processes and link social actors (1995:21). This draws on the expertise of social scientists and focuses attention on the centrality of social structural issues in explaining behavior and describing development activities. "Development is not about commodities. It is not even about new technologies or information highways. It is about people, their institutions, their knowledge, their forms of social organization" (M. Cernea 1995:17). In this scenario, the social analyst assesses existing social structural barriers to development and proposes social change strategies to reduce these barriers and create the institutional and organizational structures to facilitate development. Although this may strike some social scientists as unremarkable, it is by no means evident that any of the social science disciplines have created a codified body of knowledge regarding social structure and organization that can be readily applied in specific development contexts.

Another model sees a more modest role for social scientists. In this model, social scientists play a more advisory role, facilitating participatory efforts at the local level aimed at analyzing social and technical constraints to development. Based on these experiences, social scientists examine instances of success (or failure), communicate how wider fields of power influence local efforts, and help connect the many local efforts underway through analysis of success and failure. This approach departs from the premise that there are no magic formulas for accelerating development--however this is conceived. All efforts constitute a learning process (D. Korten 1980). Social scientists can help reduce the steepness of the learning curve. Perhaps we as social scientists can serve best as advocates for the efforts of local people, as brokers between local people and other players in the development process and witnesses to their successes, failures and the forces that oppose them. The roles proposed are considerably more humble than those of the "architects," "engineers," or "directors" of development imagined by our predecessors and colleagues of 20 or 30 years ago.

This role is also more modest than that proposed by Cernea, (who, in fact, unabashedly acclaims the role of "social engineer," M. Cernea 1991). However, the two approaches are not incompatible. The main difference is an emphasis on nomothetic principles of social structure and organization in the Cernea approach, in contrast to a more particularistic approach in the latter formulation. But, if humility and adaptive learning are prerequisites for success, there is no shame in humility. Equitable, sustainable social development is a process about which we know little. It is also an urgent necessity. 


\section{References}

Angorosino, Michael

1976. Do Applied Anthropologists Apply Anthropology? Athens: University of Georgia Press.

Anonymous

1995. Wealth Gap will Cancel Latin American Gains. Press Report on the World Bank Forum on Latin America and the Caribbean, hosted in Rio de Janeiro, June 13, 1995. Posted on the "Catrachos" list on the Internet.

Aramburú, Carlos

1984. Expansion of the Agrarian and Demographic Frontiers in the Peruvian Amazon. In Frontier Expansion in Amazonia. M. Schminck and C. Wood, editors. Gainesville: University of Florida Press.

Barber, Benjamin R.

1992. Jihad vs. McWorld. Atlantic Monthly, March 1992:53-63.

von Braun, Joachim

1995. Employment for Poverty Reduction and Food Security. Washington, DC: International Food Policy Research Institute.

von Braun, Joachim, and David Hotchkiss

1991. Income Sources of the Malnourished Rural Poor in the Western Highlands of Guatemala. In Income Sources of Malnourished People in Rural Areas: Microlevel Information and Policy Implications. J. von Braun and R. Pandaya-Lorch, editors. pp. 69-78. International Food Policy Research Institute, Working Papers on Commercialization of Agriculture, No. 5. Washington, DC: IFPRI.

Carrasco, Enrique R.

1994. Law, Hierarchy, and Vulnerable Groups in Latin America:Towards a Communal Model of Development in a Neoliberal World. Stanford Journal of International Law 30(22):221-324.

Cernea, Michael

1991. Putting People First: Sociological Variables in Development. 2nd Edition. New York and London: Oxford University Press.

1995. Social Organization and Development Anthropology. Malinowski Award Lecture. Presented at the 55th Annual Meeting of the Society for Applied Anthropology, Albuquerque, New Mexico. March 29-April 2, 1995.

Chambers, Robert, and Janice Jiggins

1987a. Agricultural Research for Resource Poor Farmers, Part 1: Transfer of Technology and Farming Systems Research. Agricultural Administration and Extension 27:35-52

1987b. Agricultural Research for Resource Poor Farmers, Part 2: A Parsimonious Paradigm. Agricultural Administration and Extension 27: 109-128

Chapin, Mac

1996. Globalization, Globaloney. Utne Reader, Jan 1996.

Collins, Jane

1988. Unseasonal Migrations: the Effects of Rural Labor Scarcity in Peru. Princeton: Princeton University Press.

Comaroff, John

1994. Democracy, Fried Chicken and the Anomic Bomb: A Brief Reflection on the "New" South Africa. Cultural Survival Quarterly. 18(2-3):34-39.

Durand, Jorge, and Douglas S. Massey

1992. Mexican Migration to the United States: A Critical Review. Latin American Research Review 27(2):3-42. 
Durham, William

1995. Political Ecology and Environmental Destruction in Latin America. In The Social Causes of Environmental Destruction in Latin America. M. Painter and W. Durham, editors. pp. 249-264. Ann Arbor: University of Michigan Press.

Elbow, Gary

1989. Central America: the Northern Sector. In Middle America: its lands and peoples (3rd edition). Robert C. West and John P. Augelli, editors. Englewood Cliffs, NJ: Prentice-Hall.

Escobar, Arturo and S. E. Alvarez

1992. The Making of Social Movements in Latin America. Boulder, CO: Westview Press.

FAO (Food and Agriculture Organization)

1988. Potentials for Agriculture and Rural Development in Latin America and the Caribbean, Annex II: Rural poverty. Rome: FAO.

Hardoy, Jorge, Dana Mitlin, and David Satterwaite 1992. Environmental Problems in Third World Cities. London: Earthscan.

Harrell, Marielouise, Cutberto Parillon and Ralph Franklin 1989. Nutritional Classification Study of Peru: Who and Where are the Poor? Food Policy, November, 1989: 313-329.

Hopenhayn, Martin

1993. Postmodernism and Neoliberalism in Latin America. Boundary 2 20(3):93-109. IFPRI (International Food Policy Research Institute)

1995. A 2020 Vision for Food, Agriculture and the Environment in Latin America. Food, Agriculture and the Environment Discussion Paper 6 (Edited by James L. Garrett). Washington, DC: IFPRI.

de Janvry, Alain, Elisabeth Sadoulet, and Linda Wilcox Young.

1989. Land and Labour in Latin American Agriculture from the 1950s to the 1980s. Journal of Peasant Studies 16(3):396-424.

Johnston, Bruce and John Mellor

1961. The Role of Agriculture in Economic Development. American Economic Review 51(4):

Jones, Jeffery R.

1990. Colonization and the environment: land settlement projects in Central America. Tokyo: United Nations University Press.

Kearney, Michael

1996. Reconceptualizing the Peasantry. Boulder: Westview Press.

Korten, David C.

1980. Community Organization and Rural Development: A Learning Process Approach. Public Administration Review 40(5:480-511).

Lewis, Arthur

1958. Economic Development with Unlimited Supplies of Labor. In The Economics of Underdevelopment. A. Argarwala and S, Singh, editors. New York: Oxford University Press.

Lipton, Michael

1977. Why Poor People Stay Poor: Urban Bias and World Development. London: Temple Smith.

Marx, Karl

1971. Peasantry as a Class. Excerpts from "The Class Struggle in France, 1848-1850" and "The Eighteenth Brumarie of Louis Bonaparte." In Peasants and Peasant Societies. Teodor Chignon, editor. pp. 229-237. Hardmonsworth: Penguin Books.

Murray, Douglas

1994. Cultivating Crisis: The Human Costs of Pesticide Use in Latin America. Austin: University of Texas Press. 
Netting, Robert McC.

1993. Smallholders, Householders: Farm Families and the Ecology of Intensive, Sustainable Agriculture. Palo Alto, CA: Stanford University Press.

Painter, Michael, and William Durham, editors.

1995. The Social Causes of Environmental Destruction in Latin America. Ann Arbor: University of Michigan Press.

Pastor, Manuel and Carol Wise

1992. Peruvian economic policy in the 1980s: from orthodoxy to heterodoxy and back. Latin American Research Review 27(2): 83-118.

Peet, Richard, and M. Watts 1994. Introduction: Development Theory and Environment in an Age of Market Triumphalism. Economic Geography 69 (3-4):227-253.

Polanyi, Karl 1944. The Great Transformation. Boston: Beacon Press.

Roseberry, William

1993. Beyond the Agrarian Question in Latin America. In Confronting Historical Paradigms: Peasants, Labor, and the Capitalist World System in Africa and Latin America. Frederick Cooper, Allen Isaacman, Florenica Mallon, William Rosebery, and Steve J. Stern, editors. Pp. 318-370. Madison: University of Wisconsin Press.

Sachs, Wolfgang

1992. The Development Dictionary: A Guide to Knowledge as Power. London: Zed Books.

Shue, Henry

1980. Basic Rights: Subsistence, Affluence and U.S. Foreign Policy. Princeton: Princeton University Press.

Solomons, Noel, and R. Gross

1987. Urban Nutrition in the Tropics: A Call for Increased Attention to Metropolitan Population in the Developing World. Food and Nutrition Bulletin. 9 (March-June 1987):43-44.

Stonich, Susan

1993. I am Destroying the Land!: The Political Ecology of Poverty and Environmental Destruction in Honduras. Boulder, CO: Westview Press.

Streeten, Paul

1979. Development Ideas in Historical Perspective. In Toward a New Strategy of Development. Alberto O. Hirschman, editor. New York: Pergammon Press.

Trenbath, R.B., G.R. Conway, and I.A. Craig

1990. Treaths to Sustainability in Intensive Agricultural Systems: Analysis and Implications for Management. In Agroecology: Researching the Ecological Basis for Sustainable Agriculture. Stephen Gliessman, editor. pp. 337-365. New York: Pergamon Press.

Vandermeer, John, and Ivette Perfecto

1995. Breakfast of Biodiversity: The Truth about Rainforest Destruction. Oakland, CA: Food First Books.

Wilken, Gene

1987. Good Farmers: Traditional Agricultural Resource Management in Mexico and Central America. University of California Press: Berkeley.

\section{Abstract}

This paper examines the effects of recent political and economic trends on the wellbeing of campesino communities in Latin America. After briefly reviewing the appropriateness of the term "campesino" in the rapidly changing political economy of Latin America, the article concludes that there is an identifiable group of people for whom 
the term campesino is appropriate and that members of campesino communities face common problems. Many analysts agree that campesino communities face interlocking social and economic crises with important consequences for the environment and the continued viability of their livelihoods. The paper analyzes these crises and their origins in the historical neglect of the rural poor. The paper concludes with some suggested actions to ameliorate these conditions, with special attention to the role of social scientists in this process.

Key words: campesino, Latin America, environment, social scientists.

\section{Resumé}

Cet article examine les effets des tendances économiques et politiques récentes sur le bien-être des communautés campesino en Amerique Latine. Après avoir passé brièvement en revue la justesse du terme "campesino" pour l'économie politique rapidement changeante de l'Amerique Latine, l'article conclut qu'il y a un groupe spécifique pour qui le terme "campesino" est à propos et que les membres des communautés campesinos fonts faces aux problèmes communes. Beaucoup d'analystes s'accordent que les communautés campesinos font face à des crises économiques et sociales qui s'imbriquent et qui ont des conséquences importantes pour l'environnement et la viabilité continuée de leurs gagnepain. L'article analyse ces crises et leurs origines dans l'indifférence historique à regard des pauvres rurales. L'article conclut avec quelques actions suggérées pour améliorer ces conditions, avec attention spéciale au rôle des spécialistes des sciences sociales dans ce processus.

Les mots-clefs: campesino, Amerique Latine, environnement, spécialistes des sciences sociales.

\section{Resumen}

Este artículo examina como las recientes corrientes políticas y económicas han afectado el bien estar de las comunidades campesinas en América Latina. Después de revisar brevemente si el término "campesino" es apropiado en la economía politíca de América Latina que esta cambiado rápidamente, el artículo concluye que hay un grupo de gente identificable a quienes el término campesino es apropiado y que miembros de comunidades campesinas enfrentan problemas comunes. Muchos analistas estan de acuerdo que comunidades campesinas enfrentan entrelazadas crisis sociales y economicas que tienen consecuencias importantes para el ambiente y de la continua viabilidad de la subsistencia campesina. Este artículo analiza estés crisis y sus origines en el falta del cuidadado históricamente dado a los pobres. El articulo concluye con algunas acciones sugeridas para mejorar estas condiciones, con atención especial dado al papel de los científicos sociales en este proceso.

Palabras claves: campesino, America Latina, el ambiente, los cientìficos sociales. 